\title{
Development of Mathematics Learning Tools Based Van Hiele Model to Improving Spatial Ability and Self-Concept Student's of MTs.S Ulumuddin
}

\author{
Zulfahmi*, Edi Syahputra, Kms. M. Amin Fauzi \\ Post Graduate Program Mathematics Education, State University of Medan, Medan, Indonesia \\ *Corresponding author: fahmiz838@gmail.com
}

\begin{abstract}
This research aims to describe: (1) product validity of learning device development based on Van Hiele model, (2) the practicality of product development of learning device based on Van Hiele model, (3) the effectiveness of product development of learning device based on Van Hiele model, (4) improvement of students' spatial skills by using the tools that have been developed based on Van Hiele model, (5) increase the ability of selfconcept students by using the device that has been developed based on Van Hiele model. The research was a development research. The development model was used 4-D model consisting of four stages, namely: Defining, designing, developing and distributing. The study to test trials was conducted on the class VIII of MTsS Ulumuddin. Test trials 1 conducted on the class VIII-2 and test trials 2 was conducted on the class VIII-3. Based on the results of the development it's showed that: (1) The valid learning tools developed with the total average validity of RPP's score was 4.50, Student Book's score was 4.30, Master Book's score was 4.30, and LAS's score was 4.40; (2) The practical learning tools developed showed based on students' activities within the prescribed tolerance limits; (3) The effective learning tools developed can be seen based on from the students' learning completeness in the classic, and achievement of learning objectives of at least $80 \%$ (4) The average achievement of students' spatial ability in the trial I was 3.15 increased to 3.51 in trial II; and (5) The average achievement of students' self-concept trial I was 3.03 increased to 3.16 on trial II.
\end{abstract}

Keywords: learning tools development, Van Hiele model, spatial ability, self-concept

Cite This Article: Zulfahmi, Edi Syahputra, and Kms. M. Amin Fauzi, "Development of Mathematics Learning Tools Based Van Hiele Model to Improving Spatial Ability and Self-Concept Student's of MTs.S Ulumuddin.” American Journal of Educational Research, vol. 5, no. 10 (2017): 1080-1086. doi: 10.12691/education-5-10-9.

\section{Introduction}

In the implementation of learning, learning tools play an important role in the learning process, as concluded from Sanjaya's statement (2009) [1] through a good and accurate planning process, teachers are able to predict how much success will be achieved. Thus the possibilities of failure can be anticipated by each teachers. Moreover the learning process will be directed and organized, and teachers can use the time effectively for the success of the learning process.

The aim of developing learning tools is to improve and produce a new product. In addition, it aims to produce learning tools that are able to solve the learning problem in the classroom, because actually there is no single source of learning that can meet all kinds of learning process needs. In other words, teachers need to think about the learning objective first, especially in improving students' mathematical abilities including the spatial ability and self-concept in order to select the learning tools.

National Academy of Science (2006) [2] suggests: "Spatial thinking serves three purposes. It has (1) a descriptive function, capturing, preserving, and conveying the appearances of and relations between objects, (2) an analytic function, enabling an understanding of the structure of objects and (3) an inferential function, generating answers to questions about the evolution and function of objects ". This explains that thinking spatially has three aims: Describing functions, analyzing functions and finding answers to an object's function. Each student should try to improve spatial ability and sensations that are useful in understanding relations and feature of geometry to solve math problems and problems of daily life.

Students have difficulty to visualize in order to solve geometry problems. This is supported by an interview with one of the teachers at MTsS Ulumuddin, M. Nur, S.Pd who said that the students were still having difficulties in understanding the issues related to solids. Those difficulties include the difficulty in visualizing images and giving the right perception of images or geometry problems.

Based on the context of everyday life, spatial ability also needs to be improved, this refers to the opinion of Barke and Engida (2001) [3] who suggested that the spatial ability not only plays an important role in the 
success of mathematics and other lessons, but also on various types of professions. In the National Academy of Science (in Syahputra, 2013) [4] it is said that many fields of science that require spatial ability in the application of science include astronomy, education, geography, geossciences, and psychology.

Some of the above statements state how important the spatial ability to be mastered by the students is, but the reality in the field is very contrary to what is expected. In fact, students' spatial abilities are still low and problematic.

In addition to spatial ability, there are aspects of psychology that contribute to the success of a person in completing the task well. In the Depdiknas (2006) [5] point five it is mentioned that the purpose of learning mathematics is that the learners are expected to have an attitude of appreciating the use of mathematics in studying the problem, as well as the attitude of resilient and confident in solving the spatial problem. It suggests that mathematics learning also emphasizes in terms of mathematical dispositions including self-concept students.

Self-concept is a person's perspective on him/herself, on his/her weaknesses and strength, including in planning the vision and mission of life. According to Seifert and Hoffnung (Desmita, 2010) [6], self-concept is an understanding of self or idea about self. Accordingly, it could be said that self-concept is the basis for being able to adapt and be formed because of a feedback process from other individuals.

Various learning models have been developed by practitioners and educational researchers in order to solve the educational problems in the field such that the Van Hiele model. To improve spatial ability mathematics and self-concept of students, a proper learning model is needed to develop that ability so that learning can stimulate students to learn independently, creatively, and more actively in following the learning activities.

According to Van Hiele, three main elements in the teaching of geometry i.e.time, teaching materials and teaching methods that are decided will be able to improve students' thinking ability to the higher levels if those elements are arranged in an integrated way. (Suherman, 2003) [7]. Some studies also reinforce the use of this model because based on research conducted by Ahdhianto (2016) [8], it was concluded that "the overall score of students after using the Van Hiele model based learning module of plane geometry was 82.8 which was in good category and meets the Minimum Criteria of Mastery Learning (KKM)". Further research was conducted by Yadil (2009) [9] that concluded that the learning scenario with Van Hiele model used can improve students' understanding.

Based on the problem that has been described, the purpose of this research are: 1) to develop the learning tools based on Van Hiele model that fulfill the valid, practical and effective criteria, 2) to describe the improvement of spatial ability and self-concept of the students by using learning-oriented model of model-based learning model Van Hiele developed.

\section{Research Method}

The category of this research is Research and Development. The development model was used the
Thiagarajan 4D development model which consisted of four development stages.

\subsection{Research Subjects and Objects}

Subjects in this study were students of class VIII-2 and VIII-3 MTs Ulumuddin academic year 2016/2017 which each class consisted of a total of 26 students. While the object in this study was a mathematics learning tool in MTs Class VIII which was orientated in developed Van Hiele model.

\subsection{Learning Tools Development}

Learning tools developed in this research were Lesson Plan (RPP), Teacher Handbook (BPG), Student Book (BS), Student Activity Sheet (LAS) and research instrument that was Spatial Ability Test of Mathematics (TKSM). Learning tools development were done by using the Thiagarajan 4D development model [10] which consisted of 4 development stages i.e: (1) Definition Stage, (2) Design Stage, (3) Development Stage, and (4) Dissemination Stage.

\subsection{Instruments and Data Collection Techniques}

The instruments used in this study included the instruments for assessing the quality of learning tools i.e. aspects of validity, practicality and effectiveness. Instruments used were observation sheets, questionnaires, and tests.

\subsubsection{The Validity of Learning Tools}

Learning tools are said to be valid if they meet the criteria of content validity and construct validity. The validity of content was done by five validators by giving score 1 to 5 in each assessment column based on aspects: (1) format, (2) language, (3) content, and (4) illustrations. Furthermore the overall expert assessment was processed by calculating the average score to obtain the criteria of content validity assessment as follows:

Table 1. Rate Validity Criteria of Learning Tools

\begin{tabular}{|c|c|c|}
\hline No & Va or Total Avarage Score & Validity Criteria \\
\hline 1 & $1 \leq \mathrm{Va}<2$ & Invalid \\
\hline 2 & $2 \leq \mathrm{Va}<3$ & Less Valid \\
\hline 3 & $3 \leq \mathrm{Va}<4$ & Valid Enough \\
\hline 4 & $4 \leq \mathrm{Va}<5$ & Valid \\
\hline 5 & $\mathrm{Va}=5$ & Highly Valid \\
\hline
\end{tabular}

Information:

$\mathrm{Va}$ is the determination score of the validity scale of the learning tools.

The Van Hiele model-based learning tools meet the expected content validity if the validator's average assessment of all learning tools is valid or highly valid. If not meet, then it is necessary to re-do the validation activities. And so on until learning tools that meet the content validity are obtained. 
Next, construct validity of spatial and self -concept spatial tests was carried out before being used for field trials. Then spatial ability test items and self-concept questionnaires were tested outside the research subjects to measure validity and reliability. To measure the validity of the item, the following correlation formula of product moment (Arikunto, 2012) [11] can be used:

$$
r_{x y}=\frac{N \sum_{x y}-\left(\sum_{x}\right)\left(\sum_{y}\right)}{\sqrt{\left\{N \sum x^{2}-\left(\sum x\right)^{2}\right\}\left\{N \sum y^{2}-\left(\sum y\right)^{2}\right\}}}
$$

Information :

$$
r_{x y} \text { : correlation coefficient between variable } \mathrm{x} \text { and } \mathrm{y}
$$

$\Sigma_{x y}$ : the number of multiplications between $\mathrm{x}$ and $\mathrm{y}$

$x$ : score of test item

$y:$ total score

$N$ : number of subjects

Furthermore, to calculate the reliability coefficient of test items, the following Alpha-Cronbach formula (Arikunto 2012) [11] was used:

$$
r_{11}=\left(\frac{k}{k-1}\right)\left(1-\frac{\sum \sigma_{b}^{2}}{\sum \sigma_{t}^{2}}\right)
$$

Information:

$$
\begin{aligned}
& r_{11}: \text { test realibility coefficient } \\
& k: \text { number of questions } \\
& \sum \sigma_{b}^{2}: \text { the number of variance scores on each questions } \\
& \sigma_{t}^{2}: \text { total variance }
\end{aligned}
$$

\subsubsection{The Practicality of Learning Tools}

The practicality of the learning tools was observed based on the validator's assessment and the implementation of learning tools. The validator assessment criteria are met if it is found on the validation sheet that all validators states that learning tools can be used with "a few revisions" or "no revision".

Furthermore, the learning tools implementation was observed based on the observer's assessment where they chose score 1 to 5 on each aspect of learning tools implementation that were Lesson Plan (RPP), Teacher Handbook (BPG), Student Book (BS), Student Activity Sheet (LAS). The average total score obtained was categorized into the following percentage of learning implementation.

Table 2. Qualification Percentage of Learning Implementation

\begin{tabular}{|c|c|}
\hline The Percentage of the implementation & Category \\
\hline$k \geq 90$ & Very Good \\
\hline $80 \leq k<90$ & Good \\
\hline $70 \leq k<80$ & Fair \\
\hline $60 \leq k<70$ & Poor \\
\hline$<60$ & Very Poor \\
\hline
\end{tabular}

Source: Sariono (2013) [12]
Information:

$\mathrm{k}=$ Average total of learning tools implementation.

The criteria of learning tools implementation are met if the minimum average total score is in the Good category.

\subsubsection{The Effectiveness of Learning Tools}

The effectiveness of instructional tools was observed based on: (1) the completeness of students' learning outcomes based on spatial and self-concept, and (2) student's responses to learning components and tools.

Completeness of student learning outcomes was seen based on the results of spatial ability test in the form of essay test consisting of five questions. The effectiveness criteria based on students' learning completeness classically are met if $\geq 85 \%$ get the score $\geq 2.67$ from the scale of four.

The activity of the students is checked on the basis of the average assessment by the observer on all aspects of the observed activity. The effectiveness criteria based on student activity are achieved when they meet the ideal percentage of time tolerance (Sinaga, 2007) [13].

Student responses were observed based on student responses to questionnaire. Effectiveness criteria based on student responses are met if $\geq 80 \%$ subject classically give a positive response [13], that is on all aspects being asked related to the learning tools and implementation.

\section{Reasearch Results}

\subsection{Description of Learning Tools Development Stage}

Learning tools development has been completed by using Thiagarajan Four-D development model with details as follows:

\section{Define}

The aim of teaching could be identified by first analyzing instructional needs. The process of identifying instructional needs began with identifying problems on the field. Based on the diagnostic tests given, the spatial ability and self-concept of students were still low. Observations and interviews with teachers and students indicated that the cause was that students were not used to spatial and self-concept ability in learning activities. This was also supported by the state of teachers who had not been able to develop learning tools that focus on developing students' spatial ability and self-concept. Based on these findings, the main objective in developing this tool is to develop and improve students' spatial ability and self-concept.

\section{Design}

The main activity of this stage was to write the initial draft of learning materials including the Lesson Plans (RPP), Teacher Handbook (BPG), Student Book (BS), Student Activity Sheet (LAS), and test of learning outcomes and questionnaires to measure students' spatial ability and self-concept. The instructional materials were based on $\mathrm{KI}, \mathrm{KD}$, and indicators on cube and block material, and adjusted to the purpose of training and 
improving students’ spatial ability and self-concept. Based on these objectives, five essays and self-concept questionnaires consisting of a total 30 questions were prepared.

\section{Develop}

At this stage an evaluation of learning tools that have been developed was carried out. Formative evaluation was done with two stages: (1) evaluation of experts and practitioners, and (2) field trials. The goals were to look at their weaknesses and improve the tools that have been developed.

The result of expert evaluation and practitioner in the form of content validity assessment showed that all learning tools met valid criteria, with average content validity of RPP $=4.50$, LAS $=4,40, \mathrm{BPG}=4,30$, and BS $=4,30$.

All of the spatial ability test items and self-concept questionnaires met valid and reliable criteria. Instrument reliability was used to determine the test result. After the calculation, reliability test of spatial ability of 0.69 (high category) and self-concept questionnaire of 0.87 (very high category) were obtained.

Field trial or trial I conducted to see the practicality and effectiveness of learning tools. In the trial I, the learning tools have not met all the practical and effective criteria, so there was a need for a revision and to do the second trial.

Revisions were made based on the findings of learning tools weaknesses in trial I. revisions were made to Lesson Plans related to learning time allocation, as well as on Student Book and Student Activity Sheet related to the materials taught. After the revisions were completed, further field trial or trial II were conducted to review the practicality and effectiveness of learning tools, as well as the improvement of students' spatial and self-concept ability between trials.

\section{Disseminate}

The dissemination stage is the final stage in the 4-D development model. At this stage, learning tools that have been used in trial in the research class will be used again by comparing the developed learning tools (experimental class) to the tools that are usually used by the mathematics teachers at MTsS Ulumuddin (control class). However, this stage was not carried out by researchers, due to the lack of time, cost and energy so that this stage is not discussed in depth.

\section{Description of the First Trial Results}

The practicality criteria of learning tools based on validator assessment were met, since all validators assessed that the developed learning tool can be used with "a few revisions" or "no revision". Implementation of learning tools was met, in terms of the average of all learning meetings that got the percentage of $81.46 \%$ (good category). Based on these descriptions, the learning tools developed meet the practical criteria.

The result of the spatial ability test showed that the total number of subjects who completed the score $\geq 2.67$ were up to 21 students from 26 students or $80.77 \%$. Description The percentage of classical completeness criteria of the spatial ability in trial $\mathrm{I}$ is shown in Figure 1.

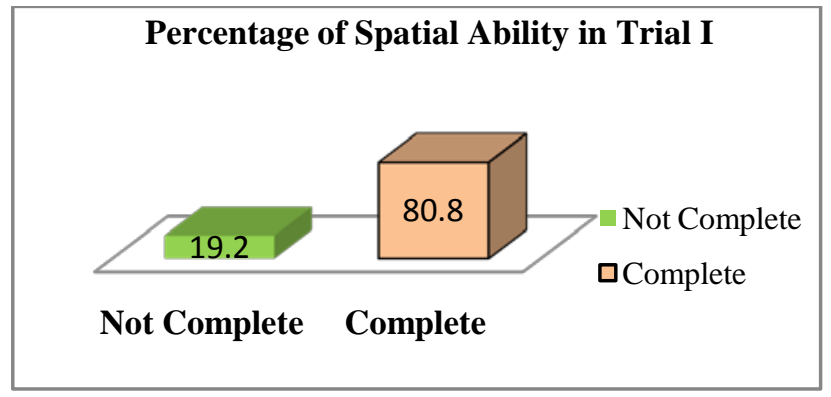

Figure 1. Percentage of Classical Completion of Spatial Ability of Students in Trial I

Based on the data in Figure 1, it can be seen that, students' learning completeness is classically from spatial ability test result in trial I. So it did not meet the completeness criteria of the expected classical learning outcomes

Further criteria of effectiveness based on student activity. The average percentage of time used by the students to conduct each activity category for 4 meetings was $23.44 \%$; $14.76 \%, 34.38 \%, 25.09 \%$ and $2.08 \%$. The average percentage is obtained from the results for the average percentage of the frequency of activity for each category with the number of meetings, which are 4 meetings. The average percentage of time students use in doing activity categories can be represented by the diagram in Figure 2.

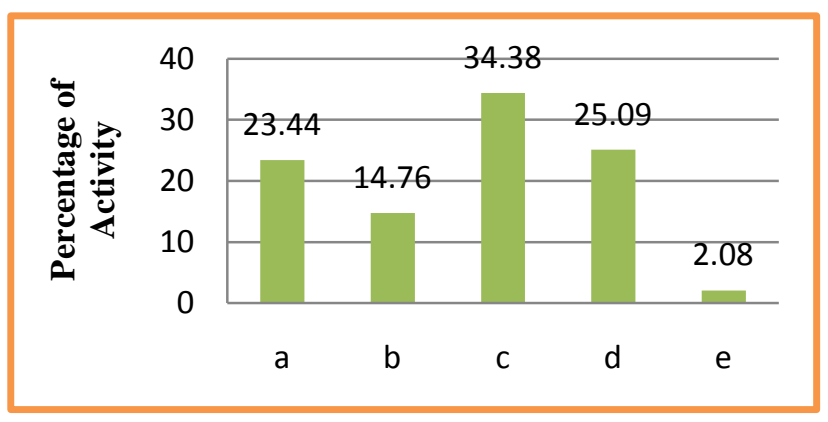

Figure 2. Presentase Diagram of Student Activity on Trial I.

Based on the data in Figure 2, it can be seen that the percentage of student activity time has met the criteria of achieving the ideal time percentage.

Then the criteria of effectiveness based on student responses were also met, because students who gave positive responses to components and implementation of learning were up to $\geq 80 \%$ i.e $94.56 \%$.

Overall, learning tools developed met the valid and practical criteria, but did not meet the criteria of effectiveness. This was because the completeness aspects of student learning outcomes had not been classically met. Thus, the learning tools should be revised. And then trial II should also be carried out.

\section{Description of the Second Trial Results}

The practicality criteria of learning tools based on the validator assessment were met in accordance with the description in the trial I. The implementation of learning tools in the second trial was also met based on the average of all learning meetings that gain the percentage of 85.14\% (good category). Based on these descriptions, the learning tools developed met the practical criteria. 
The result of the spatial ability test showed that the total number of subjects who completed the score $\geq 2.67$ reached 24 students from 26 students or $92.31 \%$. Description Percentage of classical completeness criteria of spatial ability in trial II is presented in Figure 3.

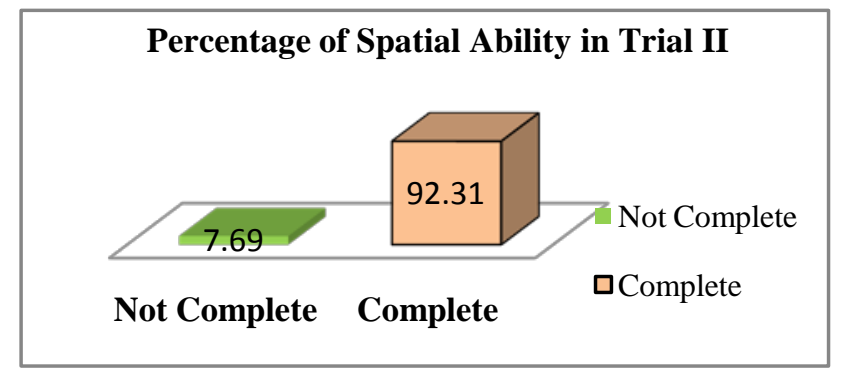

Figure 3. Percentage of Classical Completeness Spatial Ability in Trial II

Based on the data in Figure 3, it can be seen that the students' learning completeness is classically from spatial ability test result in trial II. So that in trial II already meet the completeness criteria of expected classical learning outcomes.

Furthermore, the effectiveness criteria are based on student activity. The average percentage of time that students used to conduct each activity category for 4 times was $22.74 \%$; $14.93 \%$; $34.55 \%$; $26.04 \%$; and $1.74 \%$. The average percentage is obtained from the results for the percentage of the average frequency of activity for each category with the number of meetings, which are 4 meetings. The average percentage of time students use in performing activity categories can be represented by the diagram in Figure 4.

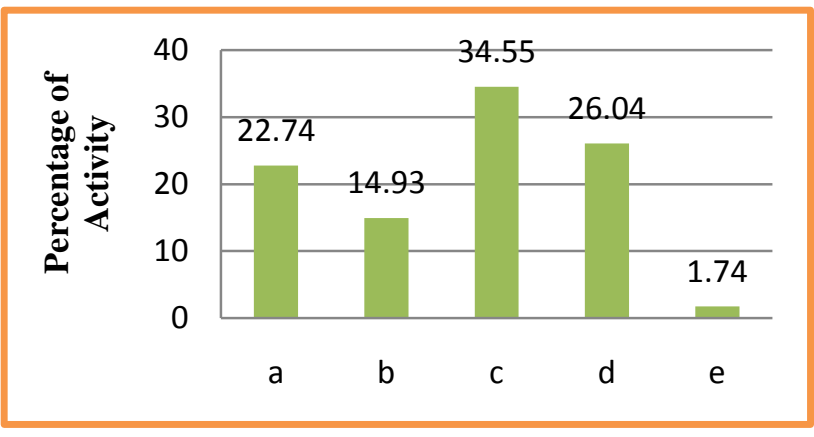

Figure 4. Presentase Diagram of Student Activity on Trial II

Based on the data in Figure 4, it can be seen that the percentage of student activity time has fulfilled the criteria of achieving the ideal time percentage.

Then the criteria of effectiveness based on student response was also met, because students who gave positive responses to the components and implementation of learning were up to $\geq 80 \%$ i.e $95.80 \%$. Overall, the learning tools based on Van Hiele model developed has met the valid, practical and effective criteria.

\section{The Improvement of Students' Spatial Ability}

The improvement of students' spatial ability was observed based on an increase in average score of spatial ability posttest from trial I to trial II. Students' post-test average score in trial I was 3,15 while in trial II became 3.51. So there was an increase of 0.36 or $9 \%$. Further improvement in students' spatial ability was also observed based on the increase of average score on each spatial ability indicator from trial I to trial II. In each indicator of spatial ability there was an increase in the average spatial ability in the indicator of the ability to recognize that the size and shape of the subject were constant despite the different stimulus of 0.48 , the indicator of the ability to imagine a change in the shape of a particular object or change the order of parts of an object of 0.35 , on the indicator of the ability to think quickly and accurately about the rotation on 2-dimensional or 3-dimensional objects of 0.23 , the indicator of the ability to understand the shape of an object or part of an object and the relationship between the object is 0.12 , and on the indicator of the ability to recognize the structure or shape of space and accurately imagine a change from a given object perspective of 0.27 . For more details we can see in the following diagram presented in Figure 5.

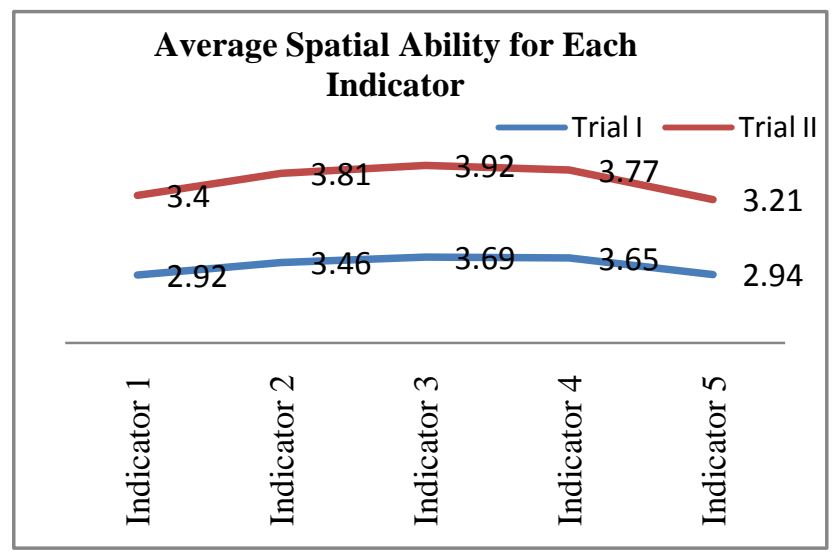

Figure 5. Average Spatial Ability for Each Indicator

Based on Figure 5 above, it can be concluded that the spatial ability of trial I to trial II is seen from the average value of total and the average value of each indicator increased through the development of learning devices based on the model of Van Hiele developed. This suggests that the use of learning tools based on Van Hiele model developed has an impact on improving students' spatial ability. This is in line with Syahputra's research (2013) [4] states that "there is a change in students' spatial ability (KS) both in the good category school as well as in the average category schools. In the good category schools, the average spatial ability (KS) of students who received realistic mathematics learning increased by 0.55 while the conventional learning increased by 0.22 . In average category schools, the average spatial ability (KS) of students who received realistic mathematics learning increased by 0.19 while students who received conventional learning increased by 0.16 ". Similarly, research conducted by Syarah et all, (2013) [14] showed that there was a difference in the spatial increase of students that was between students who got problem based learning with students who were given conventional learning. From the averages of both groups, it could be seen that students who were given problem-based learning had the higher spatial abilities than students who were given conventional learning. This was indicated by the average of the spatial gain of students who were given problem-based learning that was 0.39 higher than students' who were given regular learning that was only 0.19 . 


\section{The Improvement of Students Self-Concept Ability.}

The improvement of students self-concept were observed based on an increase in post-test average score of self-concept from trial I to trial II. The average post-test score of the students on trial I was 3.03 while in trial II became 3.16. So there was an increase of 0.13 or $3.25 \%$. Further enhancement of self-concept was also seen in each self-concept indicators: (1) Students' knowledge of mathematics; (2) Student's opinion about mathematics; and (3) Assessment of how much students love mathematics. It is pointed out that the use of learning tools based on Van Hiele model has an impact on improving student self-concept. For more details we can see in the following diagram presented in Figure 6.

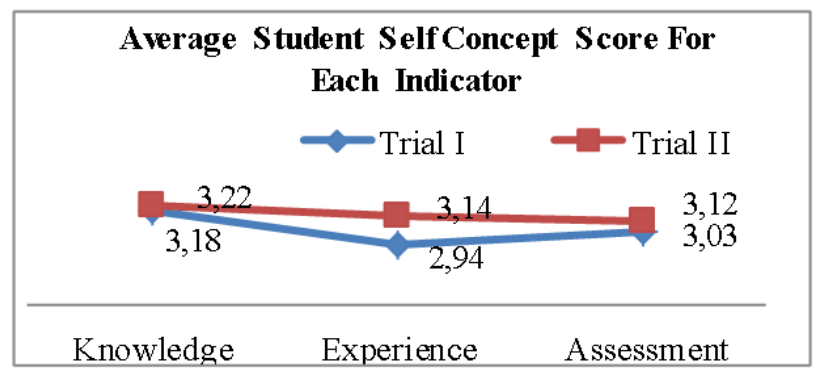

Figure 6. Self-concept Ability Charts Student's Trial I and Trial II

Based on Figure 6 above, it can be concluded that the ability of self-concept students from trial I to trial II is seen from the average value of the total and the average value of each indicator increased through the development of learning devices based on Van Hiele model developed. This shows that the use of learning tools based on Van Hiele model developed has an impact on the improvement of students' self-concept ability. In terms of improving students' self-concept abilities, for indicators of outlook and assessment is largely determined by the achievement of knowledge indicators.

\section{Conclusion}

Based on the results of data analysis and discussion in this study, presented several conclusions as follows:

a) The validity of learning tools developed included in the valid category with the total average validity of RPP's score was 4.50, Student Book's score was 4.30, Master Book's score was 4.30, and LAS's score was 4.40 , item about spatial ability test and self-concept questionnaire students have also been in the category valid.

b) Learning device developed has been practically used that has met the practical criteria seen from the student activity that the percentage of student activity time has met the criteria of achieving the ideal time percentage.

c) Learning devices developed based on the Van Hiele model have met the effective criteria. Effective criteria showed from: (1) Students' learning mastery has been classically achieved $92.31 \%$ in trial II; (2) achievement of learning objectives of at least $80 \%$; and (3) and more than $80 \%$ of students responded positively to the developed model Van Hiele learning device. d) The improvement of students spatial ability using learning tools based on Van Hiele model on cube and beam material is the average achievement of students' spatial ability in trial I was 3.15 increased to 3.51 in trial II. In addition, the average of each student's spatial indicator indicator increased from trial I to trial II.

e) The improvement of self-concept of students using learning tools developed based on Van Hiele model-based learning on cube and cube materials is the average achievement of self-concept students in trial I was 3.03 increased to 3.16 in trial II. In addition, the average of each self-concept indicator declared from trial I to trial II.

\section{Suggestions}

Based on the results of the research and the conclusion above, it can be suggested several things as follows:

a) The resulting learning tools still need to be piloted in other schools in various conditions to obtain a truly qualified learning tool (as a continuation of the deployment stage in the 4- D development model).

b) Teachers are advised to make learning device in the form of teacher book and student's own book in accordance with the characteristics of the students because more know this is the teacher itself. so that learning device can support the teacher in improving student ability.

c) In the formation of discussion groups are advised to not only pay attention to heterogeneity, but also the comfort of students in group.

d) To improve students spatial skills it is recommended that teachers focus on improving students' skills on orientation and relationships.

e) To improve the ability of self-concept students are advised that teachers focus on improving indicators of student knowledge in mathematics

\section{References}

[1] Sanjaya, W. (2009). Strategi Pembelajaran Berorientasi Standar Proses Pendidikan. Jakarta: Prenada Media Group.

[2] National Academy of Science. (2006). Learning to Think Spatially (p.32), Washington DC: The National Academics Press.

[3] Barke dan Engida. (2001). Structural Chemistry and Spatial Ability inDifferentCultures.Chemistry Education: Research and Practice in Europe 2 (3).230. pp. 227-239.

[4] Syahputra, E. (2013). Peningkatan Kemampuan Spasial Siswa Melalui Penerapan Pembelajaran Matematika Realistik. Cakrawala Pendidikan. November 2013 Th.XXXII No. 3: Yogyakarta. P. 353-357.

[5] Depdiknas. (2006). Permendiknas Nomor 22 Tahun 2006 tentang Standar Isi untuk Satuan Pendidikan Dasar dan Menengah. Jakarta: BSNP.

[6] Desmita. (2010). Psikologi Perkembangan Peserta Didik: Panduan Bagi Orang Tua dan Guru dalam Memahami Psikologi Anak Usia SD, SMP, dan SMA (p. 163). Bandung: Remaja Rosdakarya.

[7] Suherman, E. (2003). Strategi Pembelajaran Matematika Kontemporer (p. 51). Bandung: JICA.

[8] Ahdhianto, E. (2016). Pengembangan Modul Pembelajaran Geometri Bangun Datar Berbasis Teori Van Hiele Untuk Siswa Kelas VI Sekolah Dasar. Jurnal Pendidikan Dasar Nusantara, 1(2), 37-48. 
[9] Yadil, M, Nur. (2009). Penerapan Model Pembelajaran Van Hiele Untuk Meningkatkan Pemahaman Siswa SMP Karunadipa. Jurnal, Vol. 2. 88-89.

[10] Thiagarajan S., Semmel D., \& Semmel M. I. (1974). Intructional Development For Training Teachers Of Exceptional Children: A Sourcebook. Minneapolis: Central for Innovation on Teaching the Handicaped.

[11] Arikunto, S. (2012). Dasar-dasar Evaluasi Pendidikan. Jakarta: Bumi Aksara.
[12] Sariono, (2013). Kurikulum 2013: Kurikulum Generasi Emas, EJurnal Dinas Pendidikan Kota Surabaya, 3 (1), 1-9.

[13] Sinaga, B. (2007). Pengembangan Model Pembelajaran Matematika Berdasarkan Masalah Berbasis Budaya Batak (PBMB3). Disertasi tidak diterbitkan. Surabaya: Program Pacasarjana Universitas Negeri Surabaya.

[14] Syarah, F., Syahputra, E., dkk. (2013). Peningkatan kemampuan spasial dan Komunikasi Matematis Siswa SMP Melalui Pembelajaran Berbasis Masalah, Jurnal Pendidikan PPS Unimed. 9(3), 197, 189-200. 